\title{
Forms of Water Supply, Conservation and use in Banigbe District, Municipality of Ifangni, Benin (West Africa)
}

\author{
Judith Eric Georges Yetongnon ${ }^{1,2}$
}

\author{
${ }^{1}$ Department of Geography and Land Development, University of Abomey-Calavi, BP 1338 \\ ${ }^{2}$ Pierre Pagney Laboratory : Climate, Water, Ecosystems and Development (LACEEDE), University of Abomey-Calavi, B.P 526 \\ E-mail :eyetongnon@gmail.com
}

Received: 07 Mar 2021; Received in revised form: 20 Apr 2021; Accepted: 11 May 2021; Available online: 30 May 2021

\begin{abstract}
Rural populations in underdeveloped countries like Benin have difficult access to safe drinking water. This research aims to study the forms of water supply, conservation and use in Banigbé district. The methodological approach revolves around data collection through documentary research; data processing and results analysis. It appears that $88.75 \%$ of the 80 households selected for the survey in Banigbé, use at-risk sources (rivers; Private PEA; traditional wells). Only $11.25 \%$ have access to water from conventional sources such as the National Water Society of Benin (SONEB) and the Drilling of Human Motric Pumps (FPM). $88.75 \%$ of those selected for the survey also said that they do not treat drinking water at any source. It is therefore necessary to improve the quality of the water to which the populations of Banigbe have access to, and this through the disinfection of water from at risk sources and the proliferation of village hydraulic equipment in the district of Banigbé.
\end{abstract}

Keywords-Municipality of Ifangni, drinking water, water supply, conservation and water resources.

\section{INTRODUCTION}

Water is the most important natural resources. It makes life possible and supports human ecosystems and businesses. Water is therefore both a strategic resource and the fundamental building force for a healthy economy (L. Odoulami 1999, p. 17). Some years ago, water allowed the birth of great civilizations in the majority (92\%) (World Meteorological Organization and UNESCO, 1997, p. 11). Cities were developed where water was abundant in order to satisfy the then limited social, physiological and economic needs. Humanity has now reached a decisive turning point in the sense that it is now civilizations that are shaping their water resources. Population growth has led to ever-increasing water needs (Mr. Guidibi, 2010, p. 16). Water is inescapably a good and essential to human life, as air does. Access to this resource is now a huge challenge in many parts of the world (WHO 1996, p. 13).

The problems associated with access to safe drinking water in Benin are mainly due to the lack of adequate water and sanitation infrastructure (T. Adjakpa, 2002, p. 41). Nowadays, the issue of water is an integral part of today's This article can be downloaded from here: www.ijaems.com major research concerns for improving people living conditions in Benin. The various work of eminent academics such as P. Agbo (2010, p. 17) on water management on Abomey Plateau; H. Totin (2005, p. 14) on water resource management in Southern Benin lies in this perspective. In this context, Banigbé people turn to other alternatives for water. This makes these populations more concerned about access to water and less considering the questionable quality of the water they consume.

\section{MATERIALS AND METHODS}

\subsection{Study area}

The district of Banigbe is one of the six (06) districts of ifangni municipality located in southern Benin. It is located between $6^{\circ} 34^{\prime} 50^{\prime}$ and 6'40' $18^{\prime}$ of north latitude and between 2-40' 17' and 2'44' 57' of east longitude (A. A. Logbo, 2020, p. 25). The latter is located in the centre of the municipality and is limited to the north by the Boroughs of Ifangni and Lagbè, to the south by Daagbé district, to the east by Nigeria and to the west by Ko- 
Koumolou and Tchaada Boroughs. Figure 1 presents the geographical and administrative situations of the district of

Banigbé.

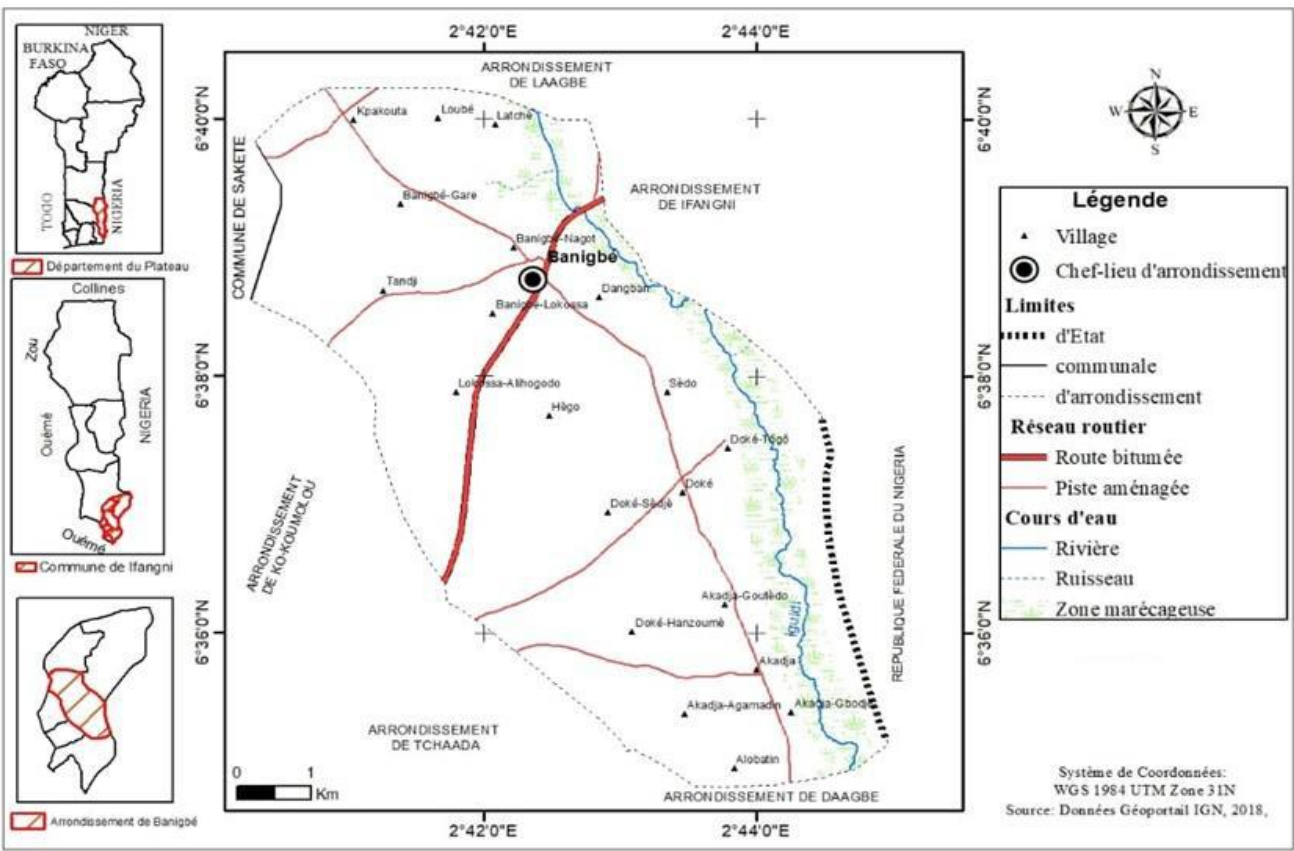

Fig.1: Geographical and administrative location of the borough of Banigbé
Figure 1 shows that the district is divided into eight villages: Akadja, Banigbé-gare, Banigbé-Lokossa, Banigbé-Nago, Dangban, Doké, Hego, Sedo. This closeness of the borough to the big Nigeria promotes various economic activities for which Nigeria is a major market. Indeed, the geographical location of the study area is subject to a wet or Beninian subequatorial climate (A. A. Logbo, 2020, p. 27). It is surrounded to the east by a swamp crossed by a small river and favors the production of off-season crops, market gardening and the setting of nurseries of diverse species. Also, ferralitic soils, clay hydromorphic soils and low-slope soils can be found. Vegetation is dominated by oil palm plantations (Elais guineensis) (A. A. Logbo, 2020, p. 29)

\subsection{Data and Methods}

\subsubsection{Data collection}

In one hand, it involved collecting all existing information through documentary research and on the other, carrying out empirical research in the field. In the field, the presurvey made it possible to know the level of understanding of these populations and provide further clarifications to the latter. The sample size at the level of each village was determined by the probabilistic theory of D. Schwartz (1995).

$\mathrm{X}$ - Z-2 x pq/i2 with $\mathrm{x}$ - sample size, $\mathrm{Z} \alpha=1,96$ reduced deviation corresponding to a $\alpha$ risk of $5 \% ; p=n / N$ with $p$ $=$ proportion of households in each village $(\mathrm{n})$ in relation to the number of households in the borough $(\mathrm{N})$ to which the latter is located, $q=1-p$ and $i=5 \%$. A total of 160 households out of the 2853 households in the borough were selected for the survey, a percentage of $5.60 \%$.

The main tools and materials used during the survey itself are: questionnaires that were sent to the main water users (household and restorer). An interview guide was used as a support for the interview of the identified resource persons (wise, village chief, the head of the National Water Society of Benin, agent of the Ouémé/Plateau water service, health worker) and a camera for shooting. Thus, three techniques are used: questionnaire survey with households, interview with resource people and direct observation in the field.

\subsubsection{Data processing}

As a result of various researches, qualitative and quantitative data were collected: both questionnaires and maintenance guides were manually stripped and the various qualitative data obtained were used as support for analyses following a thematic grouping. Quantitative data has been systematically processed under Microsoft Excel software, which allowed a few tables, graphs, and curves; thanks to MapInfo 8.0 software the maps have been made.

S. Nicholson method (2000, p. 131) made it possible to redeem surplus, loss-making and average years. According to this method, surplus years are those with annual rainfall above $120 \%$ of the series average; those with annual rainfall below $80 \%$ of the series average are said to be in 
deficit; finally, the average years are those with annual rainfall between $120 \%$ and $80 \%$ of the average in the series.

- The average of the series is obtained by the following calculation:

\section{$\mathbf{M}=\sum \mathbf{X i} / \mathbf{N}$}

M: series average

$\mathrm{Xi}$ : average annual rainfall

$\mathrm{N}$ : number of years of the period

\section{RESULTS}

\subsection{Forms of water supply, conservation and use in Banigbé district}

\subsubsection{Forms of water supply}

The forms of water supply in our rural areas have evolved over time. Given their different variations over time, two main forms stand out in Banigbé district: this is the direct recovery of rainwater and surface water, and the tap of groundwater.

\subsubsection{Recovery of rain and surface water}

Considering the 20-years period (1989 to 2018), the average $\mathrm{M}=1208.56 \mathrm{~mm}$

\section{- Precipitations}

One of the climatic factors that determine surface water in intertropical areas is rain. Its rhythm and duration determine the seasons during the year.

The district of Banigbé makes profit of sub-equatorial climate still known as beninien climate (A. A. Logbo, 2020 , p. 28). It is characterized by a relatively large rainfall exceeding $1600 \mathrm{~mm}$ at times. Four seasons are distinguished in the study area as follows:

$>$ A heavy rainy season from mid-March to midJuly;

$>$ A little dry season from mid-July to midSeptember;

$>$ A little rainy season from mid-September to midNovember;

$>$ A large dry season from mid-November to midMarch;

In recent years, an oversight of climate events made it possible to make the following remarks:

- it is well known to all that the rains start with more and more delay;

- the beginning of the rainy seasons is marked by a period of early rains that gives way to a relatively long dry period,
20 to 40 days without heavy rains and it is only after that the rainy season actually sets in. Indeed, these climatic fluctuations literally distort farmers' predictions and subject surface water to an irregular regime. Figure 2 shows the rainfall regime of the district of Banigbé.

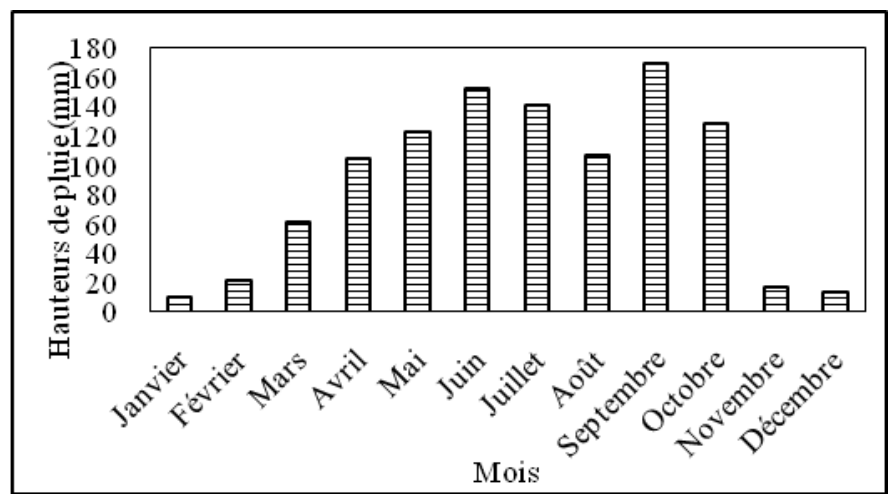

Fig.3: Average rainfall regime in the borough of Banigbé

Source: Weather-Benin, 2019

The rainfall evolution of the borough of Banigbé confirms that we are indeed in a two-mode regime, i.e. two rainy seasons and two dry seasons. Both peaks are in May - July (great rainy season) and September-October (little rainy season).

The various field observations are: regular storage, water tanks, swamp and shallow water.

\section{- Ordinary storage}

Ordinary storage occurs when cloud clusters condense and rush. Here, the rainwater is of divine origin (from Hêbiosso). During the rainy season, rainwater is a source of water. People are permanently disposed of jars under sheet metal roofs or basins to collect water. This process involves storing water directly as the rain falls.

\section{- Water cisterns}

In order to collect and store a larger volume of rainwater, some households have installed cisterns in the district of Banigbé.

Water collected by gutters installed under the ledge of the tin roofs is piped to the cistern usually installed in the courtyard of the house. Most of these structures are neglected because of the regular cracking of their cement walls, which causes water loss by infiltration, requiring frequent repairs. The top of some cisterns is carefully closed by a masonry to prevent evaporation and falling of polluting objects into the water; on the other hand, in other households, the cistern is sometimes covered with sheet metal, or simply abandoned in the open air; the most common case in Banigbé district. Plank 1 shows some cisterns. 


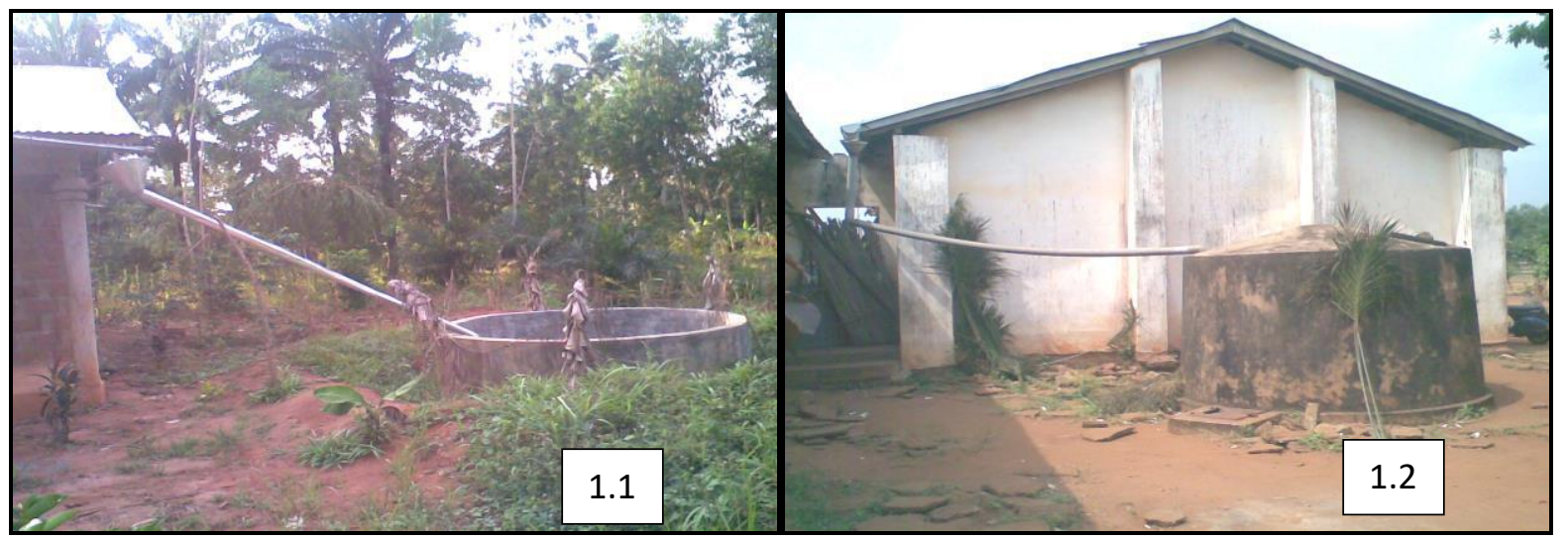

Plank 1: Partial view of an open-air cistern (1.1) and a tank closed at Dangban Public Primary School (1.2) in the district of Banigbé

Shooting: Yetongnon, March 2019

From this plank 1, the photo (1.1) shows an open-air cistern in a household in Banigbé and the photo (1.2) shows a closed cistern at Dangban Public Primary School. In fact, the storage of rainwater reduces the constraints of the drudgery and helps to conserve water. Households responded that they consume this water until the dry season "Aloun" characterized by the total absence of rain. According to them, the assessment of water quality is based on four parameters: taste, colour, smell, and temperature. Rainwater is "the one with the best quality." Indeed, it is "clear, odourless, fresh and tasteful." It is the most appreciated by the population for consumption and its supply does not require additional displacement. The consumption of water from the first rains would be the source of serious diseases because the water contains a high amount of waste piled on the roofs during the dry season.

\section{- Waters of the swamps and shallows}

This water is the favourite of the riverside populations. Indeed, the waters of the swamps have received almost the same esteem as the storm water. The swamp waters are odourless, fresh and tasteful. Photo 1 shows a partial view of the river in Dangban.

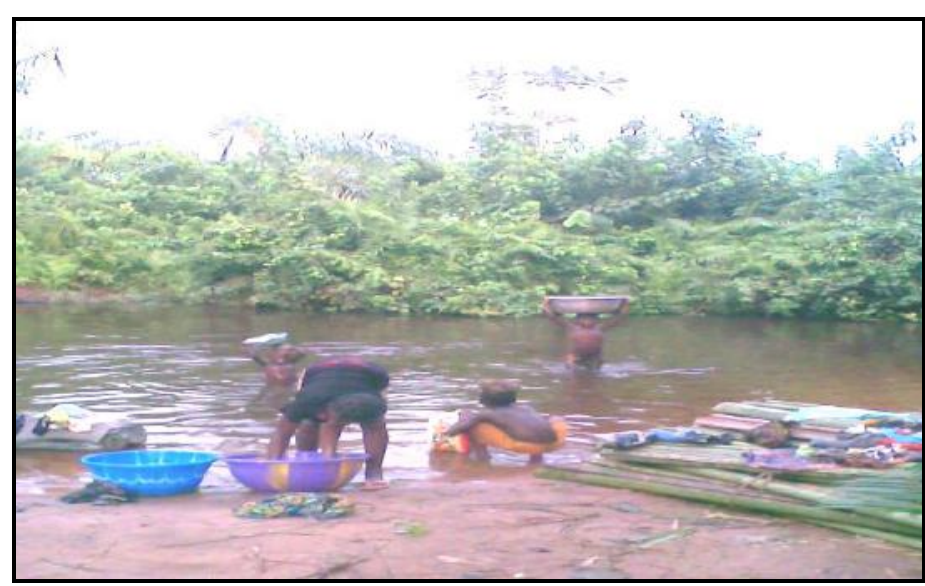

Photo 1: Partial view of the river in Dangban (Banigbé)

Shooting: Yetongnon, December 2019

Photo 1 shows that the water in this stream, which is used for the consumption by riverside populations, is also used for laundry and swimming. This situation shows the questionable nature of the quality of these waters. According to $86 \%$ of the surveys, the swamp waters are used by the population of Banigbé for various activities.

\subsubsection{Groundwater Capture}

Access to groundwater is a tricky process. It is only easy under the conditions of existence of an aquifer closer to the earth's surface. Thus, three aquifer formations can be exploited in this study. Better yet, the Continental Terminal alone contains several localized slicks, but all are unfortunately located at considerable depth (P. Agbo, 2010, p. 17). Nevertheless, people are trying to capture them in order to meet their ever-increasing water needs. Groundwater is exploited through the drilling of traditional wells, the network of the National Water Company of 
Benin, the drilling of the Water-Plateau Directorate and the Autonomous/Private Water Points.

\subsubsection{Use and conservation of water by people}

The results of water from the springs are recorded in Table I.

Table I: Use of spring water by Banigbé Households

\begin{tabular}{lccc}
\hline Source & \multicolumn{3}{c}{ Use } \\
\cline { 2 - 3 } & $\begin{array}{c}\text { Anything but drink } \\
(\%)\end{array}$ & $\begin{array}{l}\text { All } \\
\text { drink }(\%)\end{array}$ \\
\hline Wells & 2 & 98 \\
Private PEA & 0 & 100 \\
FPM & 0 & 100 \\
SONEB & 0 & 100 \\
Swamp waters & 5 & 95 \\
\hline
\end{tabular}

\section{Data Source: Field Surveys, October 2019}

The analysis of table I reveals that water from private Autonomous Water Points (PEA), Human Motricity Pumps (PMFs), the National Water Society of Benin (SONEB) is used by households for all uses including consumption; while well and swamp water are respectively used $5 \%$ and $2 \%$ for any use except the drink. What is noticed here is the design of populations on the waters of the Private Autonomous Waters Points (PEA). For the latter, the water of the private Autonomous Water Points (PEA) is drinkable more than that of traditional wells. According to $89 \%$ of respondents, they have no idea of the potential risks they face in terms of the consumption of water supplied by these Private Autonomous Water Points (AEPs). Figure 3 shows the water sources preferred by the populations of Banigbé.

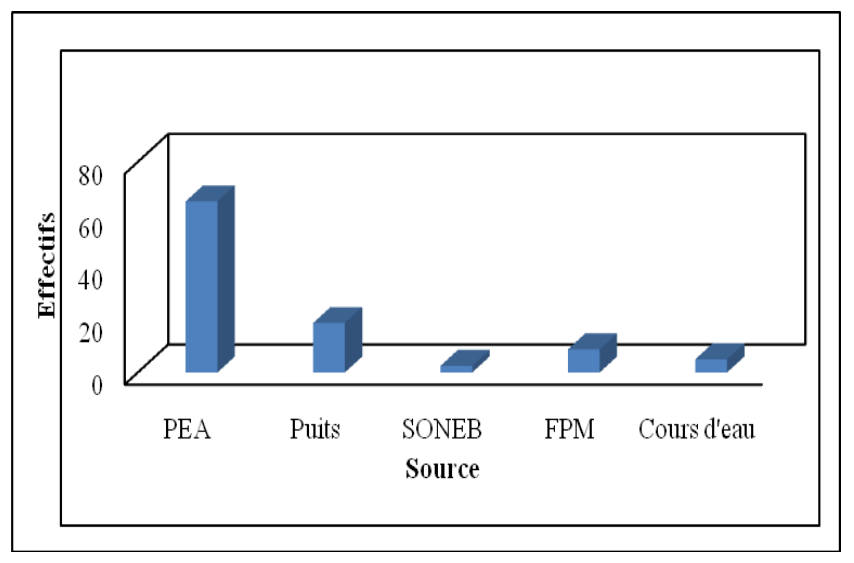

Fig.3: People's preferred water Sources

Source: Field Survey, October 2019

Figure 3 shows that five different water sources are mainly used by the populations of Banigbé for consumption and other uses. Thus, it can be said that private AEPs are the most exploited source by these populations according to $65 \%$ of those selected for the survey and that traditional wells are the second source exploited by these populations, a rate of $18.75 \%$ of those selected for the survey. Only $2.5 \%, 5 \%$, and $8.75 \%$ of those surveyed said they use SONEB water, streams and PMFs, respectively. People's preference for private AEPs is explained by their closeness to households and also by the ease and speed of its supply. It was also noted that $73.75 \%$ of households with a choice between MPFs and private AEPs preferred to source from private AEPs because of the ease and speed of supply.

For some reasons, it had been stated that the water quality of private AEPs, wells and streams of the district of Banigbé was questionable. Indeed, the populations of Banigbé are at obvious risk of frequently contracting waterborne diseases if no prior treatment is done with water before any consumption.

\subsubsection{Water conservation by the people of Banigbé}

Several means are used by the people of Banigbé to conserve drinking water. Figure 4 shows the different means of conservation.

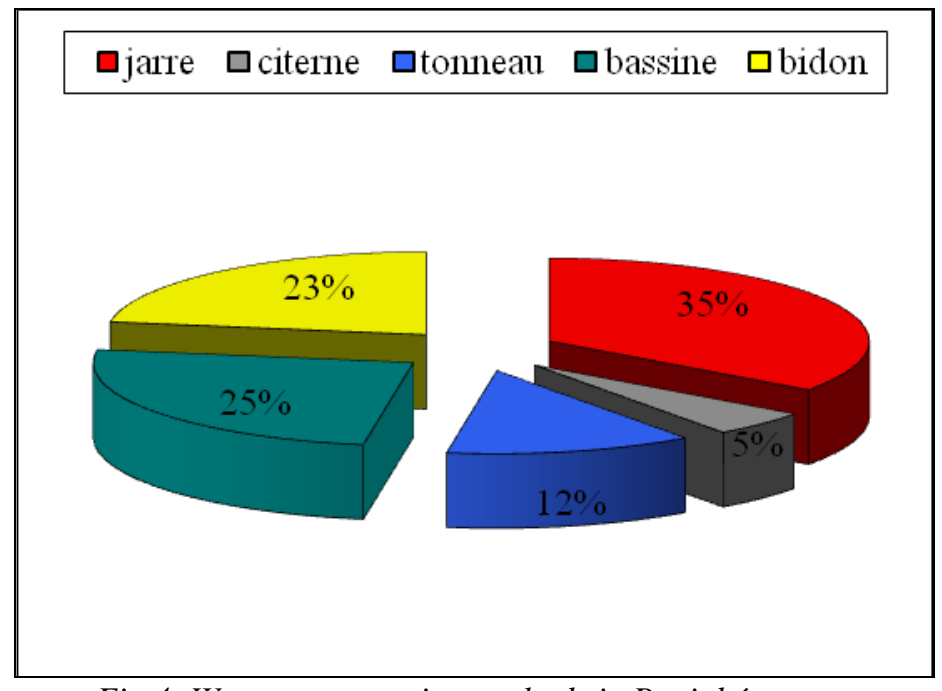

Fig.4: Water conservation methods in Banigbé.

Source: Field Survey, October 2019

Figure 4 shows that jars are the most widely used means of conservation by populations (34\% of probes), followed by basins $(25 \%)$, cans $(23 \%)$, barrels $(13 \%)$. Tanks $(5 \%)$ are also a means of water conservation, so they are not widespread in the borough.

\section{DISCUSSION}

This research has investigated the forms of water supply, conservation and use in the district of Banigbé. In fact, the 
lack of hydraulic equipment in this district forces people (women and children who return this daily chore) to run through long distances per day before accessing water and often at the level of at-risk sources. This confirms the work of Y. F. Ahehinnou (2016, p. 37) that the problem of scarcity of drinking water and the constant increase in the tap water needed by the populations of the municipality of Abomey, it is questionable. All consumers of drinking water want to urgently meet their need for drinking water. Unfortunately, given its inadequacy and the absence of sanctions that govern the non-compliance with the terms of its management; there are conflicts over the supply of drinking water in some localities in the boroughs. Despite significant efforts and investments made so far, access to water for African populations remains difficult (P. Agbo, 2010, p. 11).

In Banigbé district, the available water resources are generally significant. The average annual rainfall is between $700 \mathrm{~mm}$ and $1400 \mathrm{~mm}$. Surface water resources are estimated at 14 billion cubic meters of water and the annual groundwater recharge capacity is estimated at 1.87 billion cubic meters (National Water Partnership of Benin, 2007). But these resources are unequally distributed over the territory and great difficulties are still linked to the supply of drinking water, especially in rural areas. This copes with the research work of M. Guidibi (2010, p. 36) who showed that $56 \%$ of the Beninese population have access to drinking water, including $71 \%$ in urban areas and $47 \%$ in rural areas.

The district of Banigbe is not excluded from this general observation. In fact, the people of the borough cannot easily and fully satisfy their need for water. The surface water resources (courses and water plan) of Banigbé district do not meet expectations and the water tables present are located at high depths. This agrees with the research work of T. Adjakpa (2002, p. 49) who has shown that the poor distribution of water resources is compounded by the chronic insufficiency of hydraulic infrastructure. Most of the existing public works are in total dysfunction. According to LF Videhouenou (2019, p. 43 ), the service of the National Water Company of Benin (SONEB) only serves a minority of the population because all the inhabitants of the localities served do not have the financial capacity to subscribe. Due to these situations, the populations have no other alternatives than the drilling of traditional wells, cisterns or water holes to collect rainwater. But the water stored in cisterns and water holes cannot meet the needs of the population throughout the year. Also, the water they contain is often unsuitable for consumption because most of them are unprotected or intended to directly collect runoff. This favors the proliferation of water-borne diseases.

This article can be downloaded from here: www.ijaems.com

\section{CONCLUSION}

Water is a major economic asset for sustainable development. The district of Banigbé benefits from favorable rainfall distributed according to a bimodal regime. In order to ensure social well-being, its access to all, becomes an inalienable right but unfortunately its access is not always easy and equitable.

The district of Banigbé certainly has a relatively significant hydrological potential; but several factors limit the judicious exploitation of this resource by populations. To address this situation, measures must be taken to strengthen existing hydraulic infrastructure, establish a proper Village Water Network (AEV) and stop the expansion of the phenomenon of private AEPs in the borough. Education and awareness should also be some key actions to be carried out with people on the importance of hygiene at the level of different water sources and possible treatments to be done before any consumption of water from a suspect source such as private AEPs and rivers. This will allow us to combine with the past the various difficulties encountered by people of this district on a daily basis before obtaining drinking water.

\section{REFERENCES}

[1] Adjakpa Teodore (2002): Rural water resource management in the DASSA-ZOUME Sub-Prefecture. Master's thesis in Geography, FLASH/UAC, 88 pp.

[2] Agbo Pascal (2010): Problem of drinking water supply in the commune of Bante. Master's thesis in Geography, FLASH/UAC, $74 \mathrm{pp}$.

[3] Ahehehinnou Yedo Fidele (2016): Demographic dynamics and distribution of hydraulic works in the municipality of Abomey. Master's thesis 2 MIRD/ local development. 95 pp.

[4] Bokonon-Ganta Eutache (1987): The climates of the Gulf region of Benin. Ph.D. thesis of the 3rd cycle. Institute of Geography, University of Paris IV-Sorbonne. Paris, 248 pp.

[5] Guidibi Marcel (2010): Problem of the supply of drinking water in the commune of Allada. Master's thesis in Geography, FLASH/UAC, 78 pp.

[6] Logbo Adjimon Aimé (2020): Factors of recognition of soil fertility in connection with speculation in the district of Banigbe (ifangni commune). Geography Bachelor's Thesis, FLASH/UAC/CUA, 74 pp.

[7] Nicholson Saul (2000): Land surface processes and Sahel climate, Rev. Geophys 38(1), 117-139.

[8] Odoulami Léocadie (1999): Drinking water supply in the major cities of Benin. What policies for the future? In: Case of Cotonou, Porto-Novo and Parakou. DEA Memory, FLASH / UAC, 55 pp.

[9] WHO (1996): Report on the water and sanitation sector, $49 \%$

(C)2021 The Author(s). Published by Infogain Publication.

This work is licensed under a Creative Commons Attribution 4.0 License. http://creativecommons.org/licenses/by/4.0/ 
[10] World Meteorological Organization and UNESCO (1997): Will there be enough water on Earth?, Report 22 p.

[11] Benin's National Water Partnership (2007): Making water everyone's business. Cotonou, Report 19 pp.

[12] Totin Henri (2005): Hydroclimatic trends and water management scenarios on the southern Benin plateaus. DEA Memory, FLASH / UAC, 76 pp.

[13] Videhouenou Loiseths Ferryle (2019): Strategy to mobilize resources for local development in the municipality of Torri-bossito. Master's thesis $2 \mathrm{MIRD} /$ local development. $73 \mathrm{pp}$. 